\title{
개발협력분야 원조조달 관련 법령 개선 제언: UNCITRAL 공공조달 모델법의 활용
}

목 차

I. 서문

II. UNCITRAL과 공공조달 모델법

1. UNCITRAL 조직의 구성

2. UNCITRAL 모델법의 의의

3. UNCITRAL 모델법의 실제 도입 사례

4. UNCITRAL 모델법 활용의 중요성

III. KOICA 계약관련 규정의 특성

1. 국가계약법 및 특정조달에 관한 특례 규정존재

2. 최저가 원칙에 따른 부실화 우려

IV . 원조조달을 위한 특수규정 제언

1. 변칙적 저가 투찰자 입찰 거절 규정

2. 논의에 의한 제안서 제출

V. 결론 및 제언

참고문헌

〈Annex 1〉 실제 UNCITRAL 공공조달 모델법 조문 


\section{요 약}

한국국제협력단(Korea International Cooperation Agency, 이하 KOICA)은 1991년 창립 이래 '기타공공기관'으로 분류되어 목적사업인 국제개발협력사업에 수반 되는 각종 목적물의 조달에 있어 자체 내부 규정을 근거로 여타 공공기관과 달리 그 수단과 이행의 자율성을 보장받아 왔으나, 2016년도를 기하여 그 법적지위가 준정부 기관으로 전환됨에 따라 국가를 당사자로 하는 계약에 관한 법률 등 조달에 있어 상위 법령의 엄격한 적용을 받게 된다. 그러나 국내 내자계약을 주 내용으로 하는 이러한 법령 등이 $\mathrm{KOICA}$ 가 국외에서 실시하는 개발협력사업의 수행에 적합한지의 여부에 관하여 연구 및 검증된 이력이 없으므로, $\mathrm{KOICA}$ 사업의 특수성을 감안한 원조조달분야에 한정적으로 적용할 수 있는 대안 모색이 필요하다. 이 연구에서는 유엔 국제 무역법 위원회(United Nations Commission on International Trade Law, UNCITRAL) 의 공공조달 모델법의 예시를 통하여 국내 조달관련 법령에 존재 하지 않되 추후 목적사업의 수행을 위한 업체 선정에 적용할 수 있는 원조조달 관련 법령상의 특례를 위한 대안을 제시한다. 


\section{I. 서 문}

한국국제협력단(Korea International Cooperation Agency, 이하 KOICA)은 대한민국의

개발협력분야 전담 공공기관으로서 25년간 국제사회의 빈곤퇴치와 인류공영을 위하여 다양한 분야에서 노고를 아끼지 아니하였다. 설립 이래 KOICA는 '기타공공기관'으로 분류되어 목적사 업의 완수를 위한 각종 분야의 조달에 있어 자체 내부 규정을 근거로 여타 정부부처 또는 타 공공기관과 달리 그 수단과 이행의 자율성을 보장받아 왔다. 그러나 KOICA는 2016년 1 월을 기하여 법적 지위가 기타공공기관에서 준정부기관으로 전환됨에 따라, 기관 운영을 위한 일반 구매를 위한 조달은 물론 협력단의 목적사업인 국별협력사업 수행에 수반되는 각종 원조조 달 입찰 또한 '국가를 당사자로 하는 계약에 관한 법률' (이하 '국가계약법') 및 '공기업·준정부기 관 계약사무규칙' (이하 ‘계약사무규칙')의 엄격한 적용을 받게 되었다.

2016년도 KOICA는 전환 당시 당해 회계연도에 한정하여 이전까지 적용 중인 조달 및 계약 관련 내부 규정을 한시적으로 준용하고 있음에도 불구하고 국가계약법 및 계약사무규칙의 범위 를 벗어나지 아니하는 한도 내에서 엄격한 조달 실무를 진행하였으며, 2017년부터는 특별히 예외를 인정받지 않는 한, 조달 관련 상위 법령 및 계약사무규칙이 전면 적용된다. 그럼에도 불구하고 정부부처 운영에 필요한 조달 관련, 특히 내자구매를 위주로 하는 법령인 국가계약법 및 계약사무규칙을 KOICA의 목적사업을 위한 '원조조달'에 전면적으로 적용할 수 있는지에 대하여는 그 법령 적용 선례의 부재로 인하여 검증된 바가 없다. 요는 2017년도부터의 국가계약 법 및 계약사무규칙이 $\mathrm{KOICA}$ 의 모든 조달에 예외 없이 적용됨에도 불구하고 이로 인하여 동 사업을 효과적으로 수행할 수 있도록 보조하는 외부 업체 (용역, 물품 및 시공 모두를 포함)를 효과적으로 선정할 수 있는지는 장담할 수 없다는 것이다.

이러한 측면에서 볼 때 추후 $\mathrm{KOICA}$ 목적사업의 특수성을 감안하여 원조조달 분야에 한정적 으로 적용할 수 있는 대안을 모색하여, 향후 원조조달의 근거로 삼을 수 있는 관련 법령 또는 시행 규칙 등으로의 입안 추진이 필요하다고 할 수 있겠다. 이 연구에서는 KOICA 사업상 조달의 근거가 되는 각종 국내법령 (국가계약법)의 종류 및 특징 및 한계를 분석하고, 유엔 국제 무역법 위원회(United Nations Commission on International Trade Law, UNCITRAL) 공공조 달 모델법의 예시를 통하여 상기 국가계약법 및 계약시행규칙에 존재하지 않되 추후 목적사업의 수행을 위한 업체 선정에 적용할 수 있는 원조조달 관련 법령상의 특례를 위한 대안을 제시하고 자 한다. 


\section{UNCITRAL과 공공조달 모델법}

\section{UNCITRAL 조직의 구성}

유엔 국제 무역법 위원회(United Nations Commission on International Trade Law, 이하 UNCITRAL)는 1966년 12월 17일 유엔 총회 결의 제2205호(221)에 의하여 설립된 보조 기구로서, 국가별로 서로 다른 국내법으로 인하여 발생하는 국제 무역 거래상의 제약을 줄이고 국제 무역법의 조화와 통합을 지향함을 그 설립 목적으로 한다. 여기에서 조화와 통합이 라 함은, 국제 상거래를 촉진하는 무역법의 생성 및 채택을 의미하며, 이는 실무상에서 적용되기 에 적절하지 아니한 구시대의 법률 존재 또는 예측 가능한 실정법의 부족 등의 사태로 인한 국제 무역 및 상거래의 위축을 감지하고 이를 개선하기 위한 해결책을 제공하는 것을 의미한다. 2016년 현재 UNCITRAL에 가입한 회원국의 명단은 아래와 같다.

〈표 1〉 UNCITAL 회원국 명단

\begin{tabular}{|c|c|c|c|c|c|}
\hline 아시아-태평양 & 유럽 & 중동 & 아프리카 & 북미 & 중남미 \\
\hline $\begin{array}{l}\text { 대한민국 } \\
\text { 말레이시아 } \\
\text { 스리랑카 } \\
\text { 싱가포르 } \\
\text { 인도 } \\
\text { 인도네시아 } \\
\text { 일본 } \\
\text { 중국 } \\
\text { 태국 } \\
\text { 터키 } \\
\text { 파키스탄 } \\
\text { 필리핀 } \\
\text { 호주 }\end{array}$ & $\begin{array}{l}\text { 그리스 } \\
\text { 덴마크 } \\
\text { 독일 } \\
\text { 러시아 } \\
\text { 루마니아 } \\
\text { 벨로루시 } \\
\text { 불가리아 } \\
\text { 스위스 } \\
\text { 스페인 } \\
\text { 아르메니아 } \\
\text { 영국 } \\
\text { 오스트리아 } \\
\text { 이탈리아 } \\
\text { 체코 } \\
\text { 폴란드 } \\
\text { 프랑스 } \\
\text { 헝가리 }\end{array}$ & $\begin{array}{l}\text { 레바논 } \\
\text { 이란 } \\
\text { 이스라엘 } \\
\text { 쿠웨이트 }\end{array}$ & $\begin{array}{l}\text { 나미비아 } \\
\text { 나이지리아 } \\
\text { 라이베리아 } \\
\text { 레소토 } \\
\text { 리비아 } \\
\text { 모리셔스 } \\
\text { 모리타니아 } \\
\text { 부룬디 } \\
\text { 시에라리온 } \\
\text { 우간다 } \\
\text { 잠비아 } \\
\text { 카메룬 } \\
\text { 케냐 } \\
\text { 코트디부아르 }\end{array}$ & $\begin{array}{l}\text { 캐나다 } \\
\text { 미국 }\end{array}$ & $\begin{array}{l}\text { 멕시코 } \\
\text { 베네수엘라 } \\
\text { 브라질 } \\
\text { 아르헨티나 } \\
\text { 에콰도르 } \\
\text { 엘살바도르 } \\
\text { 온두라스 } \\
\text { 칠레 } \\
\text { 콜롬비아 } \\
\text { 파나마 }\end{array}$ \\
\hline
\end{tabular}

출처: UNCITRAL 홈페이지 요약 (http://www.uncitral.org/uncitral/en/about/origin.html) (접속일: 2016.9.30.)

UNCITRAL은 총 6개의 실무단(working group)으로 구성되어 있으며, 각 실무단의 역할 은 다음과 같다. 공공조달 관련 정책은 제1실무단 (working group I) 에서 2004년에서 2012년 
도까지 담당하였으며, UNCITRAL에서 가장 최근에 개정한 모델법은 2011년도에 제정되었다.

〈표 2〉역대 UNCITAL 실무단 활동 내역

\begin{tabular}{|c|c|c|}
\hline 실무단 & 연도 & 역할 \\
\hline \multirow{4}{*}{ Working Group 1} & 2014-현재 & $\begin{array}{l}\text { Micro, Small and Medium-sized Enterprises } \\
\text { (영세기업 및 중소기업 지원) }\end{array}$ \\
\hline & 2004-2012 & Procurement (조달) \\
\hline & $2001-2003$ & $\begin{array}{l}\text { Privately Financed Infrastructure Projects } \\
\text { (민간재원(민관협력) 사회기반시설 구축 사업) }\end{array}$ \\
\hline & $1969-1971$ & $\begin{array}{l}\text { Time-limits and Limitation (Prescription) } \\
\text { (국제상거래상의 시효에 관한 정의) }\end{array}$ \\
\hline \multirow{3}{*}{ Working Group 2} & 2000-현재 & $\begin{array}{l}\text { Arbitration and Conciliation / Dispute Settlement } \\
\text { (중재 및 조정 / 분쟁 합의) }\end{array}$ \\
\hline & $1981-2000$ & International Contract Practices (국제 계약 실무) \\
\hline & $1968-1978$ & International Sale of Goods (국제 물품 매매) \\
\hline \multirow{3}{*}{ Working Group 3} & $2010-2016$ & Online Dispute Resolution (온라인 분쟁 해결) \\
\hline & $2002-2008$ & Transport Law (운송법) \\
\hline & $1970-1975$ & $\begin{array}{l}\text { International Legislation on Shipping } \\
\text { (배송에 관한 국제 제정법) }\end{array}$ \\
\hline \multirow{4}{*}{ Working Group 4} & 1997-현재 & Electronic Commerce (전자상거래) \\
\hline & $1992-1996$ & Electronic Data Interchange (전자 문서 교환) \\
\hline & $1988-1992$ & International Payments (국제 결제) \\
\hline & $1973-1987$ & $\begin{array}{l}\text { International Negotiable Instruments } \\
\text { (국제 융통 수단) }\end{array}$ \\
\hline \multirow{4}{*}{ Working Group 5} & 2001 & Insolvency Law (도산법) \\
\hline & 2000 & International Contract Practices (국제 계약 실무) \\
\hline & $1995-1999$ & Insolvency Law (도산법) \\
\hline & $1981-1994$ & $\begin{array}{l}\text { New International Economic Order } \\
\text { (신 국제 경제 질서) }\end{array}$ \\
\hline Working Group 6 & 2000-현재 & Security Interests (담보권) \\
\hline
\end{tabular}

출처: UNCITRAL 홈페이지 내용 저자 요약정리

(http://www.uncitral.org/uncitral/en/commission/working_groups.html) (접속일: 2016.9.30.) 


\section{UNCITRAL 모델법의 의의}

국제 상거래 및 무역 촉진을 위한 UNCITRAL의 여러 활동 중 '공공조달' 분야에서 가장 상징적인 사실은 국가 내수를 위한 국내조달 및 국경을 초월하여 이루어지는 국제조달 분야에서 참고 또는 적용할 수 있는 ‘공공조달 모델법’ (이하 ‘모델법’으로 칭함) 의 제정 및 공표에 있다고 할 수 있을 것이다. 동 모델법은 공공조달 이행 시 최적가치 창출(value for money)을 지향하 고 악용을 방지하고자 하는 절차 및 개념을 포함하며, 객관성·공정성·참여 및 경쟁과 통합을 촉진하며 투명성을 그 핵심 개념으로 한다. 어느 국가든 국가의 재정 지출 중 적어도 $10 \%$ 에서 많게는 50\%까지 공공조달에 융통되며, 특히 국가의 주요 프로젝트 및 사업 (보건, 교육, 기반시 설 구축 등) 등이 공공조달을 통하여 이행되는 점을 감안할 때 한정된 자원으로 최적의 가치와 그 효율성을 극대화하는 목적 달성을 위하여 기준점으로 사용될 수 있는 규정 및 지침은 필수적 이라고 할 수 있다. 이러한 점에 부응하여, 모델법은 일반입찰, 긴급입찰 및 수의계약 등 조달에 수반되는 방식 대부분을 포괄하며 각 국가의 정부로 하여금 목적을 달성하기 위한 기준을 제공 하며, 동시에 자국의 공공조달 정책에 참고할 수 있는 법령을 실제 법령과 동일한 형식으로 제공하므로, 특히 개발도상국의 경우 이러한 국제 규범의 존재는 매우 귀중할 것이다.

\section{UNCITRAL 모델법의 실제 도입 시례}

앞서 언급한 바와 같이, 개발도상국에서는 실제로 모델법의 법령 및 강령을 준용하여 자국의 공공조달 관련 법령을 개정 또는 제정하는 데 사용하고 있다. 이를 통하여 각 국가는 시대에 맞지 않는 법령을 개정하고 조달 이행에서 발생하는 비효율성 및 비효과성을 개선하고 있으며, 현실 상거래에서 발생하는 각종 조달활동 (전자상거래, 전자조달 등)을 규제 또는 통제하는 법령의 부재를 해소하고 있다. 상기 <표 $1>$ 을 참고하면, 다른 국가와 대조적으로 아프리카 국가는 UNCITRAL 회원국으로 총 14 개 국가가 등록되어 있음을 알 수 있다. 이는 다수의 아프리카 국가는 1994년도에 최초로 UNCITRAL에 의해 제정된 공공조달 모델법을 자국의 조달 법령에 활용한 사실에 기인한다. 20세기 후반 아프리카 지역 국가의 경제 규모 발전 및 내수경기 활성화에 따른 정부 발주 (관급공사 등) 등에 소요되는 구매 및 용역을 조달하는 데 있어 과거 법령으로는 그 과정에서 발생하는 각종 분쟁 해결, 공정성 시비 등을 가리는 데 한계가 있어, 새로운 공공조달 관련 법령의 필요성이 대두되었고, 국제적인 규범으로 제정된 일종의 '표준안'으로서의 UNCITRAL 모델법을 도입한 것이다. 이는 반드시 자발적이지는 않다. 가령, 세계은행 등 국제금융기관 또는 원조 공여기관이 동 모델법의 도입을 요구 또는 독려함에 따라 도입한 경우도 존재하는데, 이는 공공조달 시 발생하는 부패 또는 부정행위 
등을 방지하여 건실한 국가 경제 및 원조 투명성 제고 등을 염두에 둔 것이라 할 수 있다. 다시 말하면, 모델법의 도입은 정부의 투명성 개선 및 부패행위 억제에도 어느 정도 영향을 준 것이다.

\section{UNCITRAL 모델법 활용의 중요성}

섹

포

커

스

제표장

필요가 있다. 우선, 동 법령의 조달은 한국 및 수원국의 상이한 공공조달 법령상의 차이를 해소 하는 데 도움을 줄 수 있다. 나라마다 경제적 수준 및 환경이 각기 다른 상황에서, 대한민국의 내자구매를 우선적으로 고려한 국가계약법 등 조달 관련 법령을 해외에서 그대로 적용하는 것은 적절하지 않을 수 있다. 물론 대한민국은 법령 적용에 있어 속인주의를 적용하여 KOICA 는 대한민국의 법령을 우선 준수할 필요가 있으나, 수원국에 상주하는 동안에는 수원국의 법률 을 적용받을 가능성이 높다. 이 두 가지 법령의 충돌 시 어느 쪽이 우선 적용되는지는 대부분 계약서상 우선순위를 미리 결정해 두어 혼동을 방지하고 있으나, 수원국의 사법체계가 이를 용인하지 않는다면 계약 분쟁 시 복잡한 (그리고 항상 외국인에게 호의적이지만은 않은) 법적 분쟁으로 이어질 가능성이 높다. 이러한 점에서, 모델법의 원칙을 $\mathrm{KOICA}$ 의 조달 원칙에 도입 하였다는 점을 국가별 협력사업에 수반되는 원조조달, 특히 현지조달의 과정 중 잠재적인 조달 참여자들에게 부각한다면, 적어도 양방 간에는 '국제 규범'에 따라 조달 과정이 진행된다는 점을 인식하여 조달 목적, 과정 및 결과 등에 있어 신뢰성 및 조달 효과성의 향상 등을 기대할 수 있을 것으로 판단된다. 


\section{KOICA 원조조달 계약의 특성}

\section{1. 국가계약법 및 특정조달 특례 규정 존재}

2016년 9월 기준으로, KOICA의 목적사업 및 기관 운영에 필요한 조달 및 계약의 근거가 되는 국내법령 및 제반 규정은 아래와 같다.

〈박스 1〉 KOICA 목적사업 및 기관운영을 위한 조달 및 계약체결 관련 법령 및 제규정

- 국가를 당사자로 하는 계약에 관한 법률 (법률 제14038호, 시행 2016.9.23)

- 특정조달을 위한 국가를 당사자로 하는 계약에 관한 법률 시행령 특례규정 (대통령령 제 제25847호, 2016.7.15)

- 공기업·준정부기관 계약사무규칙 (기획재정부령 제565호, 시행 2016.7.1)

- 공공기관의 운영에 관한 법률 (법률 제14076호, 시행 2016.9.23)

- 국가재정법 (법률 제13931호, 시행 2016.4.29)

- 국가회계법 (법률 제12844호, 시행 2014.11.19)

- 국가회계기준에 관한 규칙 (기획재정부령 제527호, 시행 2015.12.31)

* 각 법률의 동법 시행령 및 시행 규칙을 포함함 출처: 저자 정리

국가계약법의 적용 대상은 “국제입찰에 따른 정부조달계약과 국가가 대한민국 국민을 계약 상대자로 하여 체결하는 계약 [세입(歲入)의 원인이 되는 계약을 포함한다] 등 국가를 당사자로 하는 계약에 대하여 적용” 됨을 명시하고 있으며, 동 조항을 근거로 $\mathrm{KOICA}$ 는 기관 운영 입찰은 물론 협력단의 국별협력사업을 위한 원조조달 입찰 (사무소에서 실시하는 현지 입찰을 포함한 다)을 자체적으로 시행할 수 있다. 특히, 현지조달의 경우에는 상기 “특정조달을 위한 국가를 당사자로 하는 계약에 관한 법률 시행령 특례규정” (이하 ‘특례규정'이라 칭함)에 의거하여 수원국에 존재하는 현지 업체 및 법인과의 입찰 접수 및 계약 성립의 근거를 마련할 수 있다. 또한 동 규정의 적용을 받는 물품·공사 및 용역은 $\mathrm{KOICA}$ 목적 사업상 수반되는 모든 종류의 조달 목적물을 포함하므로, 실제로 KOICA가 지향하는 '원조의 비구속화 원칙'은 법적으로 근거가 마련되어 있다고 할 수 있다. 또한, 동 특례규정은 동 규정에서 정하는 바에도 불구하고 불가피한 경우에는 국제상관례에 적용할 수 있음을 명시하고 있으므로, 일부 현지조달의 경우에 는 동 특례규정의 한계를 벗어나지 않는 범주 내에서 현지 공공조달 관련 법령을 일부 적용할 수 있는 여지 또한 존재한다.1)

1) 특정조달을 위한 국가를 당사자로 하는 계약에 관한 법률 시행령 특례규정 (대통령령 제 제25847호, 2016.7.15) 제 2 조, 제 5 조 및 제 40 조 


\section{2. 최저가 입찰 원칙에 따른 부실화 우려}

그러나 상기 특례규정에도 불구하고 $\mathrm{KOICA}$ 에서 실행하는 조달 관련 절차 및 그 결과의 품질에 관하여 이해 관계자들의 우려는 여전히 상존한다. 국가계약법 및 여타 조달 법령상 낙찰자 바로 이러한 점에서 '저가 투찰로 인한 덤핑' 등 조달의 결과 및 계약상대자의 계약이행 품질에 있어 정성적인 평가를 매길 경우 부정적인 시각이 야기될 수 있다고 할 수 있다. 첨언하 면, 무리한 저가 입찰로 인하여 용역이나 시공의 품질이 저하되는 우려는 원조조달의 경우에도 예외가 아닌 것이다. 실제로 계약체결일 기준 최근 5년간(2011 2016.6) 체결된 KOICA 원조 조달입찰 554건 (수의계약 및 외부 조달 위탁 건 제외)을 계량화해 본 결과는 다음과 같다.

〈표 3〉 2011 2016.6 체결된 KOICA 원조조달입찰 554건의 낙찰결과

\begin{tabular}{|c|c|c|c|c|}
\hline 구분 & 건수 & $\begin{array}{c}\text { 평균 낙찰률 } \\
\text { (계약금액/예정가격) }\end{array}$ & 저가 낙찰 건수 & 저가 낙찰 비율 \\
\hline 협상에 의한 계약 & 420건 & $91.14 \%$ & 22건 & $5.24 \%$ \\
\hline $\begin{array}{c}\text { 최저가 및 } \\
\text { 최저가 - 적격심사 }\end{array}$ & 119건 & $83.81 \%$ & 13건 & $10.92 \%$ \\
\hline $\begin{array}{c}\text { 2단계 경쟁 } \\
\text { (기술-가격 분리) }\end{array}$ & 15건 & $88.31 \%$ & 2건 & $13.33 \%$ \\
\hline 합계 & 554건 & $89.49 \%$ & 37건 & $6.68 \%$ \\
\hline
\end{tabular}

* 저가낙찰은 낙찰률 $80 \%$ 미만에 해당하며, 수의계약은 본 수치에서 제외

출처: KOICA 전자조달시스템 계약실적대장 발췌 후 저자 정리

(https://nebid.koica.go.kr) (접속일: 2016.06.07.)

'저가 입찰'의 정의에 따라 무분별한 저가 입찰이 우려되는 경우의 수는 상이하나, 가격적 요소가 거의 절대적인 비중을 차지하는 입찰일수록 더 낮은 가격으로 낙찰되는 경향이 현저하다 고 할 수 있다. 특히 2단계 경쟁입찰의 경우 기술평가는 합격/불합격 여부만 가리고 그 후 최저가 순으로 낙찰자를 선정하기 때문에 적격심사를 병행하는 경우에 비해 낙찰률과 관계없이 $80 \%$ 미만의 낙찰 건이 차지하는 비율이 더 높게 나타났다. 낙찰률과 계약이행 품질 간의 상관관 계는 아직 $\mathrm{KOICA}$ 내부에서 분석된 바 없으나, 그럼에도 불구하고 과도한 저가 입찰을 방지할 수 있는 대책이 필요한 것은 자명하다. 계약상대자의 입장에서도 적절한 이윤이 보장되지 않으 면 적절한 계약의 이행을 기대하기 곤란하기 때문이다.2)

2) 여기에는 반론이 존재할 수 있다. "충분한 계약이행능력이 있다고 판단되는 자로서 최저가격으로 입찰한 자”에 있어, 낙찰자의 선정에는 계약이행능력 판단이 선행하며, 가격은 '계약이행능력'에 포함되는 요소가 아닐 수도 있다는 것인데, 이론상 '1원'으로 입찰을 하더라도 이것이 타 사업자를 배제하여 시장 독점적 위치를 선정하려는 의도가 아닌 이상 부당 염매로 볼 수는 없다는 것이다. 요는, 입찰참여자가 자기 비용을 감수하더라도 그만한 가치가 있다고 판단되면, 경제적 손실을 감수할 수 있는 계약이행능력이 있는 한 저가 입찰 그 자체가 조달 규정에 위배되지 않음을 의미한다. 


\section{IV. 원조조달을 위한 특수규정 제언}

\section{1. 변칙적 저가 투찰자 입찰 거절}

〈표 4〉'변칙적 저가투찰자 입찰 거절' 규정 요약

\begin{tabular}{|c|c|}
\hline 근거 & 모델법 제20조 제1항 및 제2항 \\
\hline 내용 & $\begin{array}{l}\text { 발주자가 특정 투찰이 비정상적으로 저가라고 판단되는 경우, 동 투찰에 대한 보완을 } \\
\text { 요구할 수 있으며, 계약이행능력이 의심되는 경우 해당 투찰을 무효로 처리할 수 } \\
\text { 있음 }\end{array}$ \\
\hline 장점 & 무리한 저가 투찰에 따른 덤핑 등 추후 계약 부실화 방지 가능 \\
\hline 단점 & $\begin{array}{l}\text { - 발주자의 판단이 자의적이므로 입찰의 공정성 시비 가능성 상존 } \\
\text { - 예산절감의 효과성은 상대적으로 저하됨 }\end{array}$ \\
\hline $\begin{array}{l}\text { 국내법령 } \\
\text { 배치여부 }\end{array}$ & 배치됨 (국내조달 법령상 낙찰자 선정 원칙인 ‘최저가 순 선발’과 반대) \\
\hline
\end{tabular}

출처: 손승우 (2014)

계약상대자가 변칙적인 저가 입찰을 하는 경우, 이 입찰 자체를 무효로 할 수 있는 규정은 국가계약법이나 특례규정에 존재하지 않는다. 그러나 공공조달 거래 시 분쟁 해결 및 합리적인 조달 프로세스를 위하여 준거 기준으로서 참고할 수 있는 규정인 UNCITRAL 모델법에는 이를 방지할 수 있는 조항이 마련되어 있다. 이 조항에 따르면, 발주자는 조달의 성질에 비추어 비가격적 요소를 포함하여 비정상적으로 저가로 입찰한 자에 대하여, 당해 입찰가격을 제시한 사유에 대한 소명 및 그 검토에도 불구하고 당사자의 계약이행능력이 부적절하다고 판단되는 경우에는 당사자의 입찰을 거부할 수 있다. 이는, 입찰이라는 행위에 있어 의도적으로 과도한 저가 투찰이 발생한 경우, 입찰담당자는 그 경위를 질의할 권리와, 투찰 가격으로 미루어 입찰자 의 계약이행능력을 판단할 수 있는 근거가 모두 인정될 수 있음을 의미한다. 이는 설령 ' 1 원 낙찰'과 같은 행위는 일반적인 양자 간의 계약이 아닌, 기업의 사회적 책임(CSR) 내지는 우수 기술 홍보와 같은 일종의 ‘투자’로서 행해지며, 그로 인한 낙찰자 또한 대부분 충분한 자본력을 보유한 대기업 및 그 계열사의 경우가 빈번한 현실에 비추어 볼 때, 낙찰자 선정 그 자체를 위한 무분별한 저가 입찰은 지양한다는 점에서 그 의의가 크다고 할 수 있겠다. 기실 '최저가

반론의 예시로, 최근의 1원 낙찰 사례로 국방부 병사 수신용 공용 휴대폰 임차(방위사업청 계약번호 2015UMM1375) 사업자 선정 입찰 (2단계 경쟁 (기술- 가격 동시 입찰)이 있는데, 기술평가 통과자에 한하여 최저가 입찰자가 낙찰자로 선정되는 방식으로, 결국 ' 1 원’으로 입찰가격을 제출한 L사가 낙찰자로 선정된 바가 있다. 이는 자사 비용 전액 부담으 로 휴대폰을 무상 임대해주겠다는 의도였다. 
적격심사제'의 경우 사실상 낙찰 하한률이 설정되어 과도한 저가 투찰을 방지하는 기능을 어느 정도 수행하고 있다. 그러나 투찰 가격에 있어 그 하한을 실질적으로 두고 있지 아니한 '협상에 의한 계약 체결' 등과 같은 낙찰자 선정 방식의 경우에는 그와 같은 장치가 없으므로 위와 같은 규정의 필요성이 부각된다.

\section{2. 논의에 의한 제안서 제출}

\section{〈표 5〉'논의에 의한 제안서 제출' 규정 요약}

\begin{tabular}{|c|c|}
\hline 근거 & 모델법 제30조 제2항 \\
\hline 내용 & $\begin{array}{l}\text { 일반적은 방법으로 낙찰자를 선정할 수 없어 필요하다고 인정되는 경우 가격평가나 } \\
\text { 기술평가 없이 협상만으로 낙찰자를 선정할 수 있음 }\end{array}$ \\
\hline 장점 & 잠재적 입찰자의 혁신적인 기술 등의 도입에 유용함 \\
\hline 단점 & $\begin{array}{l}\text { - 객관적 평가 기준이 없는 경우 공정성 시비 우려 } \\
\text { - 가격평가가 없으므로 예산절감의 효과성은 상대적으로 저하됨 }\end{array}$ \\
\hline $\begin{array}{l}\text { 국내법령 } \\
\text { 배치 여부 }\end{array}$ & $\begin{array}{l}\text { 부분적으로 배치됨 (군납입찰 또는 연속유찰 시 수의계약 체결 가능 사유를 제외하면 } \\
\text { 기술평가나 가격평가 없이 즉시 계약할 수 있는 경우는 통상 소액수의계약 등에 } \\
\text { 한정되며, 제안서 제출이나 협상이 필수요소는 아님) }\end{array}$ \\
\hline
\end{tabular}

출처: 손승우 (2014)

논의에 의한 제안서 제출(request for proposal with dialog)3)은 미리 규격이나 예산 한도 를 산정하기 어려운 상황에서, 민간기업의 혁신적인 최신 기술 등을 도입하는데 활용할 수 있는 조달 방식이다. 현재 국내 조달 관련 법령상 근거는 마련되어 있지 않으나, 한국은 역사적 으로 이미 비슷한 낙찰자 선정 방식을 진행한 바가 있다.4) 논의에 의한 제안서 제출 방식의 낙찰자 선정 방식은 (1) 발주자가 계약목적물에 대한 세부 사항을 정의할 수 없는 경우로서, 계약목적물의 만족스러운 공급에 있어 발주자가 계약상대자와의 논의가 필요하다고 인정되는 경우, (2) 발주자의 계약목적물이 조사, 실험, 연구 또는 개발에 해당하는 경우 (단, 계약목적물에 상업적 판로확보 또는 연구비용 충당의 목적으로 상당량의 물품 제조가 수반되는 계약은 제외), (3) 국가 안보 및 보안 유지를 위하여 동 방식이 필요하다고 인정되는 경우 또는 (4) 경쟁입찰에도

3) UNCITRAL Model Law on Public Procurement (United Nations document, A/66/17, annex I) Article30. Conditions for the use of methods of procurement under chapter $\mathrm{V}$ of this Law 제2조 참조.

4) 경부고속철도 제 1 단계 사업 당시 고속전동차 도입 및 선로 시공에 있어 세계 유수의 철도 업체와의 장기 논의 끝에 프랑스 TGV 방식을 KTX 경부선에 도입한 전례로 미루어 보아, 제도화로 이행할 수 있는 근거는 어느 정도 확보되었 다고 할 수 있다. 
불구하고 입찰자가 없거나 입찰이 취소된 경우로서, 향후 여타 낙찰자 선정 방식에 따른 입찰 진행에도 불구하고 낙찰자의 선정이 어려울 것으로 판단되는 경우 등에 활용할 수 있다. 현재 $\mathrm{KOICA}$ 에서 경쟁조건 미성립으로 인한 2회 이상 유찰 시 단일 참가자 또는 유사 계약 수행 경력자를 대상으로 한 수의계약5)이 이와 유사하다고 할 수 있다.

아울러, 현재 $\mathrm{KOICA}$ 에서 진행하는 $\mathrm{DAP}$ 6) 사업의 경우, 절차적으로 차이는 있으나 규격서, 과업지시서 또는 제안요청서가 정해지지 아니한 상황에서 사업참여 희망 업체의 혁신적인 기술과 예상 비용을 제안받아 사업자를 선정하는 CTS 프로그램 등이 이미 시행되고 있는 최근의 경향을 감안할 때, 이와 같은 방식을 도입할 수 있는 현실적인 근거는 이미 마련되었다 고 할 수 있다. 이를 조달 관련 규정으로 제도화한다면, 재래적인 조달 방식에 의존하지 않고 아이디어와 기술을 먼저 평가하여 사업에 적용하는 방식이 보다 더 강하게 뒷받침될 수 있을 것으로 기대된다. 이는 현재 시행하고 있는 $\mathrm{KOICA}$ 민관협력사업의 공모심사제를 대체 또는 보완할 수 있는 제도로서도 활용할 수 있음을 의미한다. 아울러, 국제입찰에 적용될 경우, 현지 계약상대자 선정에 있어 $\mathrm{KOICA}$ 기술평가 기준을 보완할 수 있다. 현지 입찰의 경우, 국별협력사업임에도 불구하고 ‘공모제’ 등을 통한 현지 사업자의 제안 내용을 충실히 반영하는 방식의 사업 진행에 대한 수요가 크며 아울러 기술평가 기준상의 정량정성평가 방식을 현지 실정에 그대로 적용할 수 없는 경우를 감안할 때 현지 용역계약 중 '사업수행을 보조하는 지적서비스 용역 (연구, 현지조사, 모니터링 및 평가 용역 등)' 등에 적절히 활용할 수 있을 것으로 기대된다.

5) 특례규정 제 23 조(수의계약)에 의거하여 수의계약 체결 가능 사유에는 해당하나, 기술평가 또는 제안서 검토를 명시적으 로 강제하는 규정은 없다.

6) Development Action Program : 기존 정형화된 사업 방식으로 추진이 어려운 혁신적 내용의 사업을 다양한 개발 주체와의 협업을 통해 실시하는 사업 유형으로, 주로 국내외 혁신 과학기술 발굴·사업화 및 현지 비즈니스 창출 (스타트 업) 등으로 구성되어 있다. 


\section{V. 결론 및 제언}

$\mathrm{KOICA}$ 의 목적사업에 필요한 원조조달의 이행 및 원조의 비구속화 이행을 위한 근거로서 국가계약법 및 특례규정 등 국제조달과 현지조달을 실시할 수 있는 법적 기반이 마련되어 있음 에도 불구하고, 종래의 낙찰자 결정 방식의 원칙인 '최저가격 입찰자' 선정의 원칙의 한계로 인하여 입찰의 부실화 및 사업수행 품질의 저하 등의 우려는 아직 해소되지 아니하였다. 이를 보완하기 위하여 종래 관련 국내법령에 존재하지 아니하는 '변칙적 저가 투찰 거부' 및 '논의에 의한 제안요청'과 같은 방법론적 대안을 UNCITRAL 공공조달 모델법에서 활용할 수 있을 것이다.

그러나, $\mathrm{KOICA}$ 사업 및 동 사업에 수반되는 원조조달의 특수성은 $\mathrm{KOICA}$ 내부 임직원들이 바라보는 시각과 외부의 시각 (참여 희망 업체, 유관 정부부처 및 시민사회) 반드시 동일하지는 않는다는 점을 상기해야 할 필요가 있다. 요는, 저가투찰 거부와 논의에 의한 제안서 제출과 같은 방식이 공공조달이라는 제도로 편입되기 위하여는 도입의 필요성 및 합리성에 대한 사회적 함의가 견고하여야 하고, 원조조달 분야에 대하여 도입하기 위해서는 KOICA 개발협력 사업에 대한 객관적 지식이 외부에 충분히 알려져야 할 필요가 있는 것이다.7) 또한, 낙찰자 선정 방식은 발주자가 결정하는 만큼, 논의에 의한 제안서 제출 등 입찰 참여 희망자의 제안에 의존하는 방식의 경우, 이러한 방식을 적용하는 이유에 대한 설명은 온전히 $\mathrm{KOICA}$ 의 몫으로 남는다는 점 또한 기억해야 한다.

그럼에도 불구하고, 이와 같은 대안은 지금까지 대한민국 공공조달 상 도입된 적이 없었던 제도인 만큼, 제도 도입 및 시행에 있어서는 충분한 사전 검토 및 시범운영 도입 등 그 효과성 및 결과에 대한 분석이 수반되어야 추후 제도로서의 입안의 정당성을 강화시킬 것이라 할 수 있겠다. 가령, 향후 시행 시 국내 입찰 참가자들의 이해관계를 고려했을 때 기존 제도와의 상충. 잠재적 국내 입찰 참가자들에 대한 갈등 및 $\mathrm{KOICA}$ 의 법적 지위상 전면적인 특례 인정의 현실적 어려움 등을 감안하여 본부 조달보다는 해외사무소 주도로 이루어지는 현지 입찰 및 현지계약 등에 선별적으로 적용할 수 있는 대안으로 선 도입 후, 결과 및 효과성에 대한 분석이 수반된 후에 추후 $\mathrm{KOICA}$ 는 물론 국가계약법의 적용을 받는 모든 기관에 범용적으로 적용할

7) 현재 공공조달에 있어 우선순위가 부여되는 중소기업, 소상공인, 여성 및 장애인 우대기업 등의 경우, 이러한 규정 도입이 오히려 공정한 경쟁 및 시장 진입을 방해할 수 있다는 점에서 모든 입찰에 대한 전면적인 도입은 바람직하지 않다고 할 수 있다. 이와 같은 사업자는 중소기업 및 소상공인 제한 업종에서, 견적 수의 대상 등 비교적 1 건당 1 억 원 미만의 소액 계약을 체결하는 경우가 대부분이며, 특례규정 또한 이러한 사업자를 배제하는 경우는 국제조달의 경우 등과 같이 매우 엄격하게 제한하고 있다. 
수 있는 법령 개정안 등으로 발의할 수 있을 것이다.

이상의 UNCITRAL 모델법의 조문을 활용한 개정된 규정의 적용을 통하여 KOICA가 준정 부기관으로서 의무적으로 준수해야 하는 기존 계약 및 입찰 관련 법률의 한계를 보완할 수 있으며, 고품질의 $\mathrm{KOICA}$ 의 목적사업 이행은 물론 기존 조달 관련 법령의 한계를 초월한 혁신 적인 민간 분야의 기술 도입 또는 현지에서의 역량 있는 사업자 선정을 위한 법적 근거로서 작용할 수 있어 다각화된 사업의 수행을 위한 법적 기반이 강화될 것으로 기대된다. 


\section{〈참고 문헌〉}

남일총. 1996. “삼성항공의 1원 낙찰사건은 부당염매인가.” 『경쟁저널』 Vol. 7:37-43.

손승우. 2014. "UNCITRAL 정부조달 모델법 분석을 통한 국내 조달법령의 개선방안 연구(2)- 개정(안) 마련을 중심으로.” 서울: 한국법제연구원.

. 2013. 『UNCITRAL 정부조달 모델법 분석을 통한 국내 조달법령의 개선 방안 연구』. 서울: 한국법제연구원.

C. Nicholas. 2011. "Work of UNCITRAL on government procurement: purpose, objectives, and complementarity with the work of the WTO." Geneva: UNCITRAL.

G. Quinot and S. Arrow. 2013. "Procurement methods in the public procurement systems of Africa," Public Procurement Regulation in Africa, Cambridge: Cambridge University Press: 261-5.

박효현. “권영수 LG유플러스 부회장 ‘군대 공짜폰' 지원, 국방부로부터 감사패.” 서울경제 (2016.02.15.기사). http://news.naver.com/main/read.nhn?mode=LSD\&mid= sec\&sid1=105\&oid=011\&aid=0002799588（접속일: 2016.06.07）

UNCITRAL. "Origin, Mandate and Composition of UNCITRAL" posted on United Nations Commission on International Trade Law (UNICITRAL) website, available at http://www.uncitral.org/uncitral/en/about/origin.html (접속일: 2016.9.30.)

. "FAQ - Origin, Mandate and Composition of UNCITRAL" posted on United Nations Commission on International Trade Law (UNICITRAL) website, available at http://www.uncitral.org/uncitral/en/about/origin_faq. html. (접속일: 2016.9.30.)

"Working Group Documents" posted on United Nations Commission on International Trade Law (UNICITRAL) website, available at http://www. uncitral.org/uncitral/en/commission/working_groups.html (접속일: 2016. 9.30.) . "UNCITRAL Model Law on Public Procurement (2011)" http://www.uncitral.org/uncitral/en/commission/working_groups.html (접속일: 2016.9.30.) 


\section{〈Annex 1〉 실제 UNCITRAL 공공조달 모델법 조문}

I. [Article 20] Rejection of abnormally low submissions (변칙적 저가 입찰 거부)

1. The procuring entity may reject a submission if the procuring entity has determined that the price, in combination with other constituent elements of the submission, is abnormally low in relation to the subject matter of the procurement and raises concerns with the procuring entity as to the ability of the supplier or contractor that presented that submission to perform the procurement contract, provided that the procuring entity has taken the following actions:

(a) The procuring entity has requested in writing from the supplier or contractor details of the submission that gives rise to concerns as to the ability of the supplier or contractor to perform the procurement contract; and

(b) The procuring entity has taken account of any information provided by the supplier or contractor following this request and the information included in the submission, but continues, on the basis of all such information, to hold concerns.

2. The decision of the procuring entity to reject a submission in accordance with this article, the reasons for that decision, and all communications with the supplier or contractor under this article shall be included in the record of the procurement proceedings. The decision of the procuring entity and the reasons therefore shall be promptly communicated to the supplier or contractor concerned.

П. [Article 30] Conditions for the use of methods of procurement under chapter $\mathrm{V}$ of this Law (two-stage tendering, requests for proposals with dialogue, requests for proposals with consecutive negotiations, competitive negotiations and single-source procurement) (논의에 의한 제안서 제출)

1. [Subject to approval by the [name of the organ designated by the enacting State to issue the approval]], a procuring entity may engage in procurement by means of request for proposals with dialogue in accordance with article 
49 of this Law where:

(a) It is not feasible for the procuring entity to formulate a detailed description of the subject matter of the procurement in accordance with article 10 of this Law, and the procuring entity assesses that dialogue with suppliers or contractors is needed to obtain the most satisfactory solution to its procurement needs;

(b) The procuring entity seeks to enter into a contract for the purpose of research, experiment, study or development, except where the contract includes the production of items in quantities sufficient to establish their commercial viability or to recover research and development costs;

(c) The procuring entity determines that the selected method is the most appropriate method of procurement for the protection of essential security interests of the State; or

(d) Open tendering was engaged in but no tenders were presented or the procurement was cancelled by the procuring entity pursuant to paragraph 1 of article 19 of this Law and where, in the judgment of the procuring entity, engaging in new open-tendering proceedings or a procurement method under chapter IV of this Law would be unlikely to result in a procurement contract. 